\title{
Phenotypic heterogeneity of impacted third molar tooth: family case study
}

\author{
Albu C. ${ }^{1 *}$, Ion G. ${ }^{2}$, Milicescu S. ${ }^{3}$, Albu S. ${ }^{4}$ \\ DOI: https://doi.org/10.17511/ijmrr.2019.i05.13 \\ 1* Cristina-Crenguta Albu, Lecturer, Department of Genetics, University of Medicine and Pharmacy "Carol Davila", Bucharest, Romania. \\ 2 George Ion, Assistant Professor, Department of Prosthodontics, University of Medicine and Pharmacy "Carol Davila", Bucharest, Romania. \\ 3 Stefan Milicescu, Lecturer, Department of Prosthodontics, University of Medicine and Pharmacy "Carol Davila", Bucharest, Romania. \\ 4 Stefan-Dimitrie Albu, DMD, Alco San Medical Center, Bucharest, Romania.
}

Tooth impaction is a pathological condition where a tooth fails to attain its normal functional position. The present study aims to highlight the phenotypic heterogeneity of impacted third molars in a Caucasian family, to investigate the characteristics of the dental phenotype, to evidence the diversity of dental phenotype, and to identify the inheritance mode of the condition. Detailed anamnesis, clinical examination, complementary tests (panoramic radiographs), family study and pedigree analysis. Phenotypic characteristics of impacted third molar tooth in our family case report was: Severe horizontal impaction of the mandibular right third molar, Angular impaction of the maxillary right third molar and angular impaction of the maxillary left third molar, Angular impaction of the mandibular left third molar and partial eruption of the maxillary right third molar, Horizontal impaction of the mandibular left third molar and Angular impaction of the mandibular left third molar. The inheritance mode of the impacted third molar tooth in the family case report was: from mother to both daughters' transmission, from mother to both sons' transmission, and from mother to daughter transmission. Family study and pedigree analysis are very important for illustrate the genetic basis of impacted teeth.

Keywords: Impacted teeth, Third molar, Dental phenotype, Inheritance mode

Corresponding Author

Cristina-Crenguta Albu, Lecturer, Department of Genetics, University of Medicine and Pharmacy "Carol Davila", Bucharest, Romania.

Email: crenguta.albu@yahoo.com
How to Cite this Article

Albu C, Ion G, Milicescu S, Albu S. Phenotypic heterogeneity of impacted third molar tooth: family case study. Int J Med Res Rev. 2019;7(5):437-442. Available From https://ijmrr.medresearch.in/index.php/ijmrr/article/ view/1090
To Browse

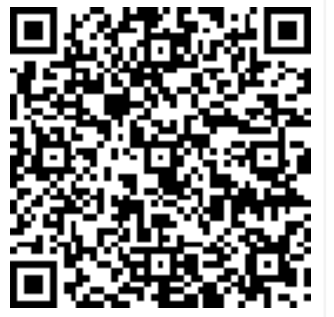

Manuscript Received 2019-09-24

Conflict of Interest No

Review Round 1
2019-10-04
Funding
Nil

Funding (C) 2019 by Cristina-Crenguta Albu, George Ion, Stefan Milicescu, Stefan-Dimitrie Albu and Published by Siddharth Health
Research and Social Welfare Society. This is an Open Access article licensed under a Creative Commons Attribution 4.0 International License hittps://creativecommons.org/licenses/by/4.0/ unported [CC BY 4.0].

\author{
Review Round 2 \\ 2019-10-10 \\ thical Approval \\ Review Round 3
}

Accepted 2019-10-16

Note 


\section{Introduction}

Tooth impaction is a pathological situation where a tooth fails to attain its normal functional position [1]. Impacted teeth are completely or partially unerupted and are positioned against another tooth, bone or soft tissue [2]. Commonly impacted teeth are: mandibular third molar, maxillary third molar, maxillary canine, mandibular premolar, maxillary premolar, mandibular canine, maxillary central incisor and maxillary lateral incisor [3]. Impacted teeth may remain asymptomatic or may be associated with various pathologies: periodontal bone loss, root resorptions, cysts or tumors and tooth decay $[1,4]$. Impaction of the third molar is occurring in up to $73 \%$ of young adults in Europe $[5,6]$. Most authors claim that the incidence of mandibular third molar impaction is higher in females [6-8].

The etiology of impacted teeth is very diverse and multifactorial. The causes of impaction are local causes of impaction (lack of space due to underdeveloped jaws, lack of a coarse, abrasive diet - an attritive diet - the major cause in modern civilization, chronic inflammation, premature loss of primary teeth or ankylosis of primary or permanent tooth, ectopic position of tooth bud) or systemic causes of impaction, prenatal (heredity and linked disorders, like osteoporosis or cleft palate), postnatal (rickets, anemia, congenital syphilis, tuberculosis, malnutrition, endocrine dysfunction of thyroid, parathyroid or pituitary gland) and rare conditions (cleidocranial dysplasia, oxycephaly, progeria, achondroplasia, cleft palate) $[2,3,9,10]$. The unerupted and impacted tooth is a common problem and the reason for many orthodontic and pediatric dental referrals, yet the approach to their management is still an area of controversy [11].

\section{Case report}

A Caucasian male patient, aged 24, along with his family, present in a private dental practice in Bucharest, Romania, for a routine dental examination. The correct diagnosis of dental impaction requires a detailed anamnesis, clinical examination, and the use of complementary tests to ensure that the correct treatment decisions are made [12]. The clinical examination for all family members was performed in artificial light, using a dental unit, dental mirror and ball-ended probes, after tooth brushing and air-drying, based on the World Health Organization protocol [13, 14].
Digital panoramic radiographs were obtained using a Digital Panoramic X-ray Unit, CRANEX Novus (Manufactured by SOREDEX, Tuusula, Finland), operating at $70 \mathrm{kV}$.

The panoramic radiographs were evaluated on a computer monitor (21-inch LCD monitor), under dim lighting conditions.

Family study and pedigree analysis were performed to determine the genetic basis of impacted teeth.

Phenotypic characteristics of impacted third molar tooth in our family case report was:

- Case no. 1: Mother, II4: severe horizontal impaction of the mandibular right third molar (Figure 1);

- Case no. 2: First soon, proband III7: angular impaction of the maxillary right third molar and angular impaction of the maxillary left third molar (Figure 2);

- Case no. 3: Second soon, III8: angular impaction of the mandibular left third molar and partial eruption of the maxillary right third molar (Figure 3);

- Case no. 4: Mother's sister, II5: horizontal impaction of the mandibular left third molar (Figure 4);

- Case no. 5: Daughter, III9: angular impaction of the mandibular left third molar (Figure 5).

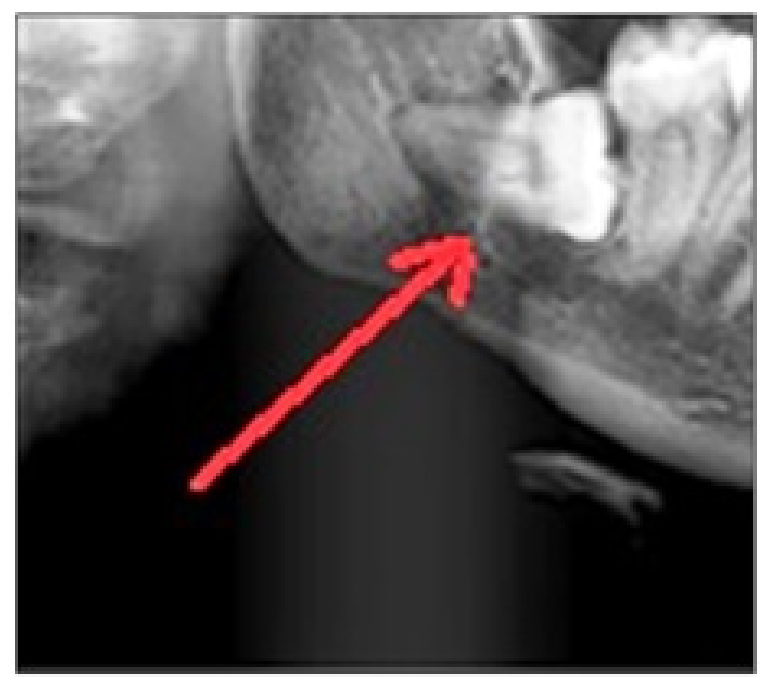

Figure 1 - Case no. 1: Mother, II4: severe horizontal impaction of the mandibular right third molar 

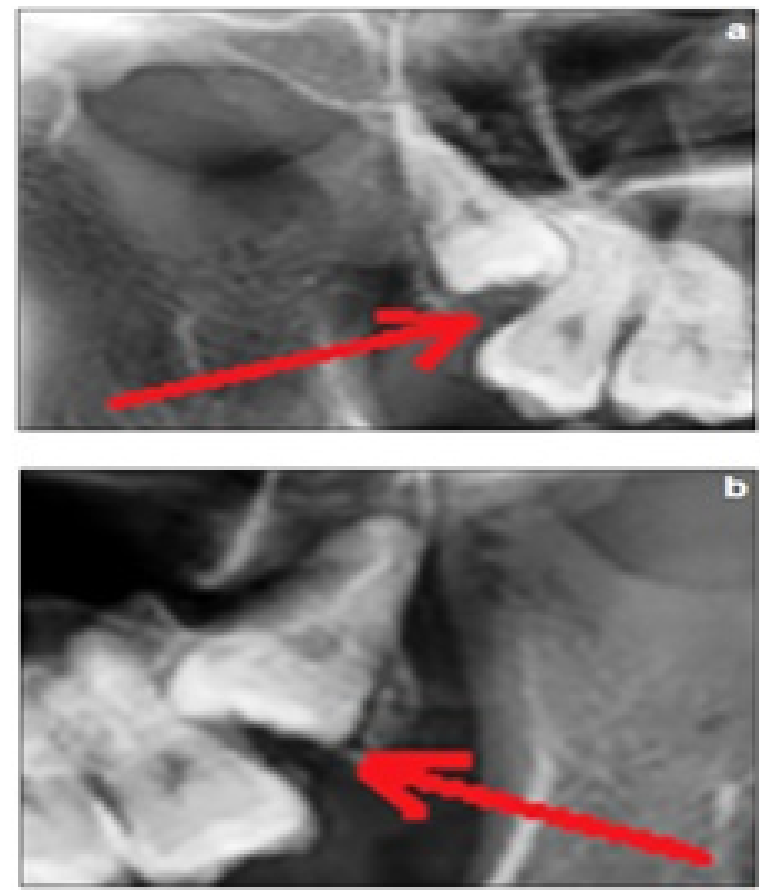

Figure 2 - Case no. 2: First soon, proband III7: angular impaction of the maxillary right third molar (a) and angular impaction of the maxillary left third molar (b).
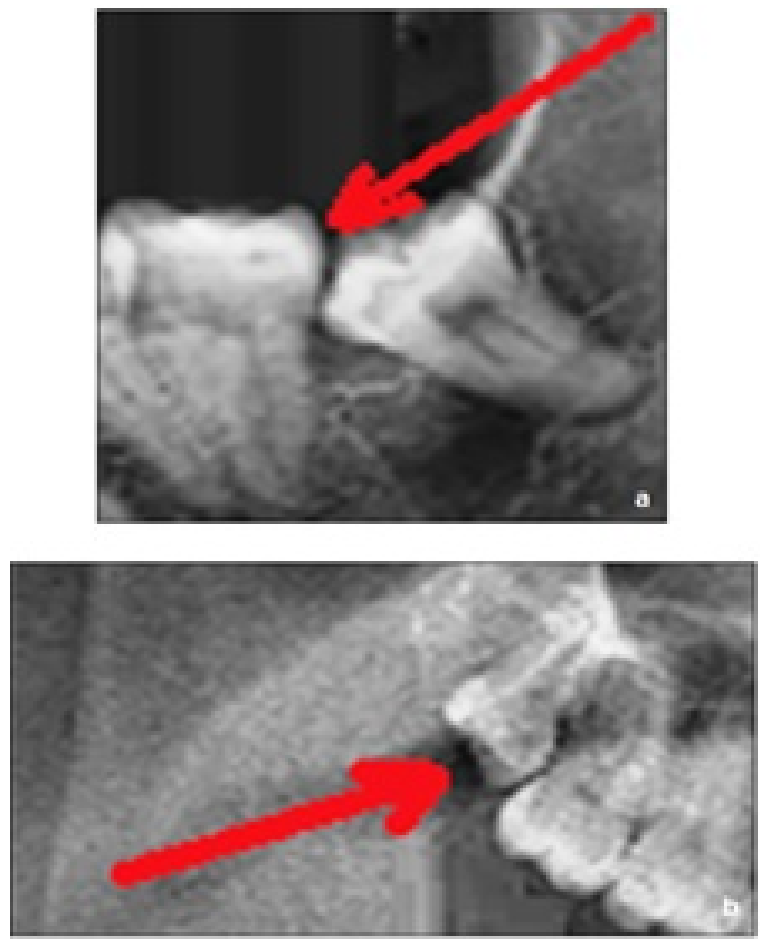

Figure 3 - Case no. 3: Second soon, III8: angular impaction of the mandibular left third molar (a) and partial eruption of the maxillary right third molar (b).

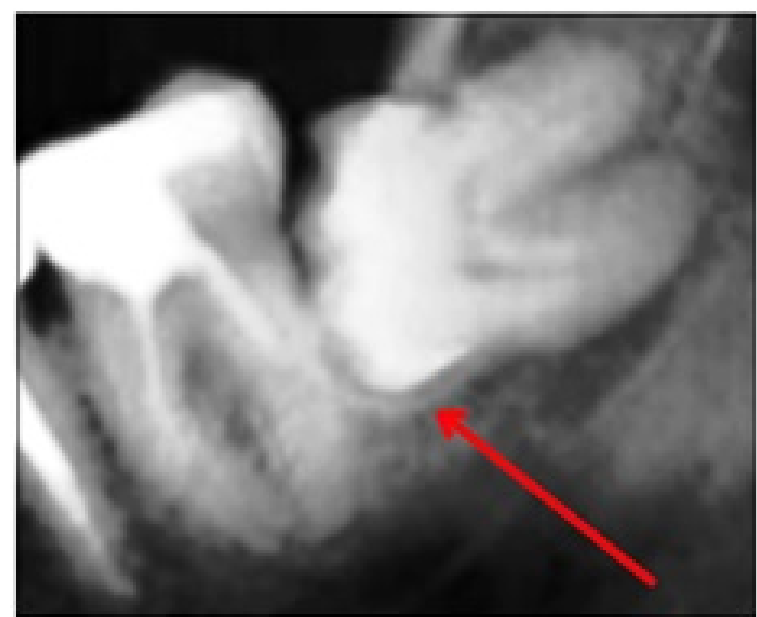

Figure 4 - Case no. 4: Mother's sister, II5: horizontal impaction of the mandibular left third molar

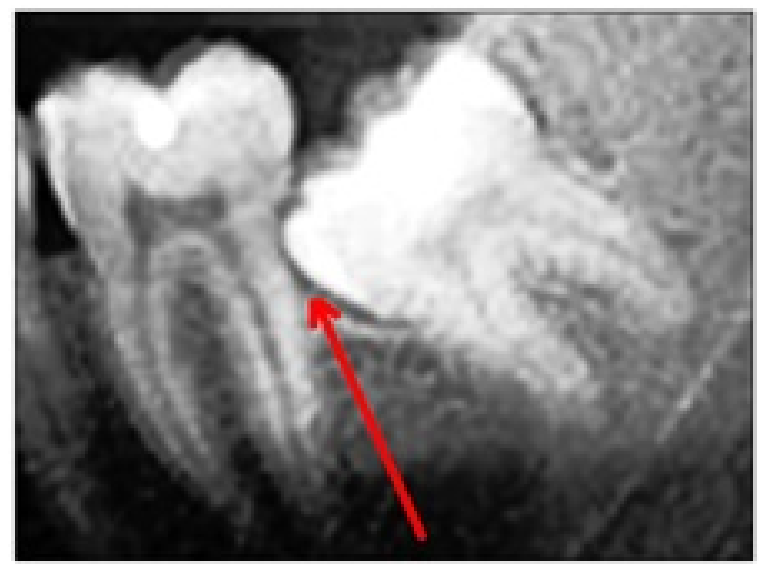

Figure 5 - Case no. 5: Daughter, III9: angular impaction of the mandibular left third molar

The inheritance mode of the impacted third molar tooth in the family case report was: from mother (I1) to both daughters transmission (II4 and II5), from mother (II4) to both sons transmission (III7 and III8), and from mother (II5) to daughter transmission (III9), (Figure 6).

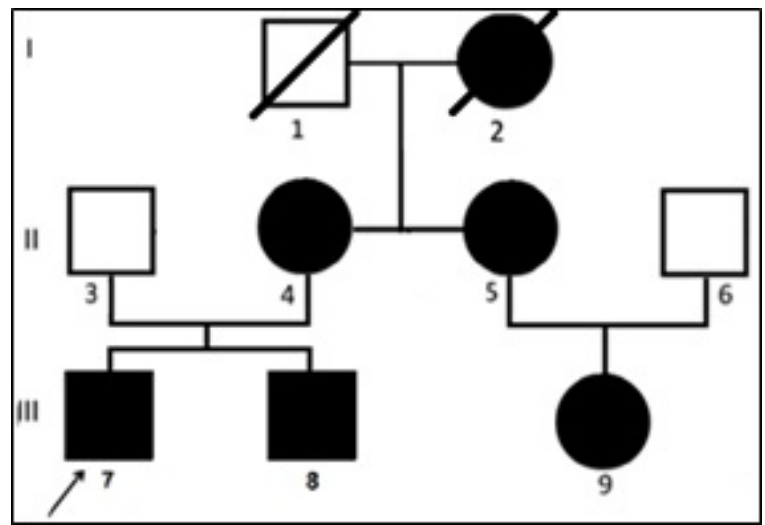


Figure 6 - Family case report: The inheritance mode of the impacted third molar tooth.
The results of the study are summarized in the Table 1.

Table - 1: Family case report.

\begin{tabular}{|c|c|c|c|}
\hline \multicolumn{4}{|c|}{ Family case report } \\
\hline \multirow[t]{3}{*}{$\begin{array}{l}\text { Phenotypic } \\
\text { characteristics }\end{array}$} & $\begin{array}{l}\text { Case no. } 1 \text { - II4: } \\
\text { severe horizontal impaction of the } \\
\text { mandibular right third molar }\end{array}$ & $\begin{array}{l}\text { Case no. } 1 \text { - II4: } \\
\text { severe horizontal impaction of the mandibular right third molar }\end{array}$ & $\begin{array}{l}\text { Case no. } 4 \text { - II5: } \\
\text { horizontal impaction of the } \\
\text { mandibular left third molar }\end{array}$ \\
\hline & $\begin{array}{l}\text { Case no. } 4 \text { - II5: } \\
\text { horizontal impaction of the mandibular } \\
\text { left third molar }\end{array}$ & $\begin{array}{l}\text { Case no. } 2 \text { - III7: } \\
\text { angular impaction of the maxillary right third molar and angular } \\
\text { impaction of the maxillary left third molar }\end{array}$ & $\begin{array}{l}\text { Case no. } 5 \text { - III9: } \\
\text { angular impaction of the } \\
\text { mandibular left third molar }\end{array}$ \\
\hline & & $\begin{array}{l}\text { Case no. } 3 \text { - III8: } \\
\text { angular impaction of the mandibular left third molar and partial } \\
\text { eruption of the maxillary right third molar }\end{array}$ & \\
\hline $\begin{array}{l}\text { The inheritance } \\
\text { mode }\end{array}$ & Mother to both daughters' transmission & Mother to both sons transmission & Mother to daughter transmission \\
\hline
\end{tabular}

\section{Discussion}

Impacted teeth are those with a delayed eruption time or that are not expected to erupt completely based on clinical and radiographic assessment [15].

Impacted third molars are commonly encountered in routine dental practice [1].

The number of people reaching adult life with impacted third molars seems to be increasing to an epidemic extent [16].

Physical barriers (e.g., overetained primary teeth, supernumerary teeth, and pathologic lesions), space problems, dietary changes of modern civilization, developmental abnormalities, altered eruption sequence, trauma, palatal clefts, and genetics can act as etiologic factors of impacted teeth $[10,17]$.

A precise early diagnosis is essential to evaluate the possible outcomes related to unerupted third molars and to reduce treatment time, complexity, complications and cost $[12,18,19]$.

In cases of unerupted or impacted teeth, a multidisciplinary approach is indicated involving geneticians, orthodontists, paedodontists and oral surgeons to establish the optimal prediction and treatment plan [11].

In the future, additional studies are desired in order to more clearly illustrate the genetic basis of impacted teeth and the long-term effects on occlusal development caused by eruption disturbances of impacted third molar tooth [20].

\section{Conclusion}

Family study and pedigree analysis are very important for possible prevention, early diagnosis of the dental phenotype and treatment options for impacted teeth, as well as the timing of any interceptive treatment.

\section{Reference}

01. Santosh P. Impacted Mandibular Third MolarsReview of Literature and a Proposal of a Com bined Clinical and Radiological Classification. Ann Med Health Sci Res. 2015;5(4)229-234. doi: 10.4103/2141-9248.160177 [Crossref]

02. Janakiraman EN, Alexander M, Sanjay $P$. Prospective analysis of frequency and contributing factors of nerve injuries following third-molar surgery. J Craniofac Surg. $2010 ; 21(3) 784-786$.

doi: $10.1097 /$ SCS.0b013e3181d7f29a [Crossref]

03. Shapira Y, Kuftinec MM. Tooth transpositions-a review of the literature and treatment con siderations. Angle Orthod. 1989;59(4)271-276. doi: 10.1043/0003-z219(1989)059<0271:TTAROT>2. $0 . \mathrm{CO} ; 2$ [Crossref]

04. Sarica I, Derindag G, Kurtuldu E, Naralan ME, Caglayan F. A retrospective study- Do all impacted teeth cause pathology?. Niger J Clin Pract. 2019;22(4)527-533.

doi: 10.4103/njcp.njcp_563_18 [Crossref] 
05. Khan NB, Chohan AN, Al Mograbi B, Al Deyab S, Zahid T, Al Moutairi M. Eruption Time of Permanent First Molars and Incisors Among a Sample of Saudi Male School children. Saudi Dent J. 2006;18;18-24.

[Crossref]

06. Juodzbalys G, Daugela P. Mandibular third molar impaction- review of literature and a proposal of a classification. J Oral Maxillofac Res. 2013;4(2)e1.

doi: $10.5037 /$ jomr.2013.4201 [Crossref]

07. Kruger E, Thomson WM, Konthasinghe P. Third molar outcomes from age 18 to 26- findings from a population-based New Zealand longitudinal study. Oral Surg Oral Med Oral Pathol Oral Radiol Endod. 2001;92(2)150-155. doi: 10.1067/moe.2001.115461 [Crossref]

08. Yuasa $H$, Sugiura M. Clinical postoperative findings after removal of impacted mandibular third molars- prediction of postoperative facial swelling and pain based on preoperative variables. $\mathrm{Br} \mathrm{J}$ Oral Maxillofac Surg. 2004;42(3)209-214.

doi: $\quad 10.1016 /$ j.bjoms.200402.005 [Crossref]

09. Zengin $A Z$, Sumer AP, Karaarslan E. Impacted primary tooth and tooth agenesi- a case report of monozygotic twins. Eur J Dent. 2008;2(4)299-302.

[Crossref]

10. Lytle JJ. Etiology and indications for the management of impacted teeth. Northwest Dent. $1995 ; 74(6) 23-32$.

[Crossref]

11. Andrade I Jr, Paschoal MA2, Santos TO3. Spontaneous Eruption of Severely Impacted teeth- The Report of Two Cases. J Clin Exp Dent. 2019;11(5)e491-e495.

doi: $10.4317 /$ jced.55514 [Crossref]

12. Oenning AC, Neves FS, Alencar PN, Prado RF, Groppo FC, Haiter-Neto F. External root resorption of the second molar associated with third molar impaction- comparison of panoramic radiography and cone beam computed tomography. J Oral Maxillofac Surg. 2014;72(8)1444-1455.

doi: $10.1016 /$ j.joms.2014.03.023 [Crossref]
13. Kassawara AB, Tagliaferro EP, Cortelazzi KL, Ambrosano GM, Assaf AV, Meneghim Mde C, et al. Epidemiological assessment of predictors of caries increment in 7-10- year-olds- a 2-year cohort study. J Appl Oral Sci. 2010;18(2)11620.

doi: 10.1590/s1678-77572010000200004 [Crossref]

14. Farah CS1, Harmon DM. Tongue piercing- case report and review of current practice. Aust Dent J. $1998 ; 43(6) 387-389$. doi: 10.1111/j.1834-7819.1998.tb00197.x [Crossref]

15. Thilander B, Jakobsson SO. Local factors in impaction of maxillary canines. Acta Odontol Scand. $1968 ; 26(2) 145-168$.

doi: $10.3109 / 00016356809004587$ [Crossref]

16. Adaki SR, Yashodadevi BK, Sujatha S, Santana $\mathrm{N}$, Rakesh $\mathrm{N}$, Adaki $\mathrm{R}$. Incidence of cystic changes in impacted lower third molar. Indian J Dent Res. 2013;24(2)183-187. doi: $10.4103 / 0970-9290.116674$ [Crossref]

17. Noorollahian S, Shirban F. Chair time saving method for treatment of an impacted maxillary central incisor with 15-month follow-up. Dent Res J. 2018;15(2)150-154.

[Crossref]

18. Almendros-Marqués N, Berini-Aytés L, GayEscoda C. Influence of lower third molar position on the incidence of preoperative complications. Oral Surg Oral Med Oral Pathol Oral Radiol Endod. 2006;102(6)725-732.

doi: $10.1016 /$ j.tripleo.2006.01.006 [Crossref]

19. Richardson G, Russell KA. A review of impacted permanent maxillary cuspids-diagnosis and prevention. J Can Dent Assoc. 2000;66(9)497501.

[Crossref]

20. Bondemark L, Tsiopa J. Prevalence of ectopic eruption, impaction, retention and agenesis of the permanent second molar. Angle Orthod. $2007 ; 77(5) 773-778$.

doi: $10.2319 / 072506-306.1$ [Crossref] 